\title{
AKTIVITAS ANTIBAKTERI KITOSAN MONOSAKARIDA KOMPLEKS SEBAGAI PENGHAMBAT BAKTERI PATOGEN PADA OLAHAN PRODUK PERIKANAN
}

\author{
Selly Ratna Sari ${ }^{1 *}$, Ace Baehaki ${ }^{2}$, Shanti Dwita Lestari ${ }^{2}$, Elmeizy Arafah ${ }^{3}$, Guttifera ${ }^{1}$ \\ ${ }^{1}$ IImu Perikanan, Fakultas Pertanian, Universitas Sumatera Selatan \\ ${ }^{2}$ Teknologi Hasil Perikanan, Fakultas Pertanian, Universitas Sriwijaya \\ ${ }^{3}$ Agribisnis, Fakultas Pertanian, Universitas Sumatera Selatan \\ Diterima: 23 September 2020/Disetujui: 23 Desember 2020 \\ Korepodensi : sellyratnasari@uss.ac.id
}

Cara sitasi: Sari SR, Baehaki A, Lestari SD, Arafah E, Guttifera. 2020. Aktivitas antibakteri kitosan monosakarida komplek sebagai penghambat bakteri patogen pada olahan produk perikanan. Jurnal Pengolahan Hasil Perikanan Indonesia. 23(3): 542-547.

\begin{abstract}
Abstrak
Penelitian ini bertujuan untuk menentukan aktivitas antibakteri pada komplek kitosan monosakarida (glukosa, galaktosa dan fruktosa) terhadap Vibrio cholerae. kitosan monosakarida kompleks dibuat dengan cara memodifikasi kitosan dengan gula monosakarida yang disterilisasi menggunakan autoklaf dengan variasi $1 \%$ glukosa, $1 \%$ galaktosa dan $1 \%$ fruktosa. Analisis dibuktikan dengan menguji aktivitas bakteri $V$. cholerae yang sering digunakan untuk indikasi bakteri pathogen pada produk perikanan. Pengunaan kitosan dan gula monosakarida diduga dapat menghambat $V$. cholera yang merupakan indikator bakteri patogen produk perikanan. Kitosan yang dimodifikasi menujukkan lebih baik dibandingkan penggunaan kitosan tanpa modifikasi (kontrol). Kitosan dengan modifikasi fruktosa menunjukkan daya hambat tertinggi $V$. cholerae yaitu $9 \mathrm{~mm}$.
\end{abstract}

Kata kunci : perikanan, fruktosa, galaktosa, glukosa sterilisasi

\section{Antibacterial Of Chitosan Monosaccharide Complex As An Inhibitor Of Pathogenic Bacteria For Fishery Products}

\begin{abstract}
The purpose of this research was to determine antibacterial activity of chitosan monosaccharide complex (glucose, galactose and fructose) against Vibrio cholerae. Chitosan monosaccharide complex was made by modifiying chitosan disinfecting monosaccharides used autoclaving that had variation $1 \%$ glucose, $1 \%$ galactose and $1 \%$ fructose. Analysis had been proved by testing bacterialactivity of V.cholerae which are frequently used for indications pacthogenic bacteria of fishery product. It is Suspected that chitosan and Monosacarides can inhibit $V$. cholera as pathogenic bacteria of Fish Product. Modified Chitosan shows better than the use of chitosan without modification (control). Chitosan with fructose modification indicates highest power of $V$. cholerae is $9 \mathrm{~mm}$.
\end{abstract}

Keyword: fishery, fructose, galactose, glucose, sterilization

\section{PENDAHULUAN}

Aktivitas antibakteri pada kitosan monosakarida komplek telah terbukti dapat menghambat beberapa bakteri misalnya Pseudomonas aeruginosa dan Bacillus subtilis indikator bakteri perusak makanan (Sari et al. 2019). Beberapa penelitian perbaikan biomaterial menggunakan kitosan sebagai bakteri juga berhasil dimodifikasi (Liang et al. 2020). Kitosan-monosakarida digunakan sebagai pengawet surimi ikan gabus (Lestari et al. 2019). Komoditas yang telah diawetkan menggunakan kitosan sudah cukup banyak diantaranya surimi ikan gabus, pembuatan edible film gelatin kitosan dengan tambahan genjer pada produk pempek (Ali et al. 2017), coating kitosan dengan konsentrasi 3\% dapat mempengaruhi mutu dan umur simpan daging ikan giling gabus (Toynbe et al. 2015) dan pengawetan buah longan (Lin et al. 2019).

Kitosan dapat menghambat pertumbuhan 
beberapa bakteri karena memiliki potensi antioksidan sebagai pengawet (Sari et al. 2013). Penggunaan larutan kitosan sebagai film pelapis filet ikan salmon dan pangan laut pada suhu $5{ }^{\circ} \mathrm{C}$ menghasilkan jumlah TVB, TPC dan $\mathrm{pH}$ yang rendah (Baptista et al. 2020). Pemanfaatan kitosan sebagai antibakteri belum secara maksimal salah satunya untuk kerusakan makanan yang disebabkan oleh bakteri patogen olahan produk perikanan. Solusi penelitian yang telah dilakukan adalah dengan penambahan jenis gula. Gula dapat bereaksi dengan kitosan membentuk suatu reaksi Maillard sehingga dapat membentuk antioksidan lebih baik sebagai indikator perusak makanan olahan ikan (Bakry et al. 2018). Diduga penambahan kitosan $1 \%$ dan gula monosakarida $1 \%$ contohnya glukosa, galaktosa dan fruktosa yang disterilisasi dapat menghambat bakteri pada olahan perikanan misalnya Vibro cholera.

Kitosan monosakarida membentuk reaksi Maillard yang terbukti dapat melawan bakteri perusak makanan dan bakteri patogen serta memiliki antioksidan (Mahae et al. 2011), sedangkan penambahan berbagai macam gula (laktosa, arabinosa dan galaktosa) dapat menghambat $P$. aeruginosa, S. aureus, Escherichia coli dan Bacillus cereus (Mahae et al. 2011). Modifikasi kitosan dengan beberapa gula dan aktivitasnya dalam menghambat beberapa bakteri sudah dilakukan namun, belum ada yang diujikan terhadap Vibrio cholera. Bakteri ini menjadi salah satu indikator bakteri patogen produk olahan perikanan, misalnya kerang-kerangan. Pengunaan bahan alami misalnya kitosan dan monosakarida dapat menghambat pertumbuhan bakteri yang merugikan ikan maupun produk olahan ikan. Sehingga Penelitian ini harus segera dikembangkan untuk menjadi solusi untuk menghambat bakteri patogen makanan seperti olahan produk khususnya perikanan. Oleh karena itu, penelitian ini bertujuan menentukan aktivitas antibakteri pada komplek kitosan monosakarida (glukosa, galaktosa dan fruktosa) terhadap bakteri $V$. cholerae.

\section{BAHAN DAN METODE Bahan dan Alat}

Bahan utama penelitian ini adalah kitosan dari PT Vital House Indonesia, V. cholera dari Badan pengawasan obat dan makanan (BPOM), glukosa (Merck), galaktosa (Merck), fruktosa (Merck) dan akuades dari Teknologi Hasil Pertanian UNSRI. Bahan kimia yang digunakan untuk analisis adalah nutrient broth (OXOID), nutrient agar (OXOID), alkohol $70 \%$ (Merck), asam asetat 98\% (Merck),

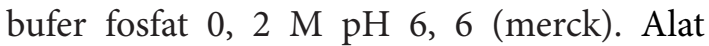
yang digunakan meliputi autoklaf (Hirayama HL36AE, Jepang), cawan petri, inkubator (Memmert IN55, Jerman), laminar air flow, neraca analitik, spektrofotometer (Shimadzu UV1800, Jepang), tabung reaksi, timbangan analitik (Fujitsu Electronic.co.id), dan vortex (Gemmy 300, Taiwan).

\section{Metode Penelitian}

Penelitian ini menggunakan metode deskriptif dengan melihat daya hambatnya terhadap $V$. cholerae. Perlakuan yang diberikan adalah perbedaan kompleks Kitosan monosakarida yang diulang sebanyak tiga kali. Penelitian ini terdiri dari beberapa tahap kegiatan (Mahae et al. 2011), antara lain preparasi larutan asam asetat, pembuatan larutan kitosan dengan variasi monosakarida, pembuatan kompleks kitosan monosakarida (CMC), dan pengujian antibakteri. Metode penelitian dapat dilihat pada Figure 1.

\section{Preparasi larutan asam asetat (Mahae et al. 2011)}

Asam asetat glasial diambil sebanyak $1,02 \mathrm{~mL}$ (98\% menjadi 1\%) dan ditambahkan dengan akuades hingga mencapai $100 \mathrm{~mL}$ atau sampai garis tanda, kemudian dihomogenkan.

\section{Pembuatan larutan kitosan dengan variasi monosakarida (Mahae et al. 2011)}

Kitosan ditimbang sebanyak $1 \mathrm{~g}(1 \%)$ dan dimasukan ke dalam gelas beaker, dilarutkan dengan $1 \%$ larutan asam asetat sebanyak 50 $\mathrm{mL}$ dan di-stirrer selama \pm 30 menit (sampai 


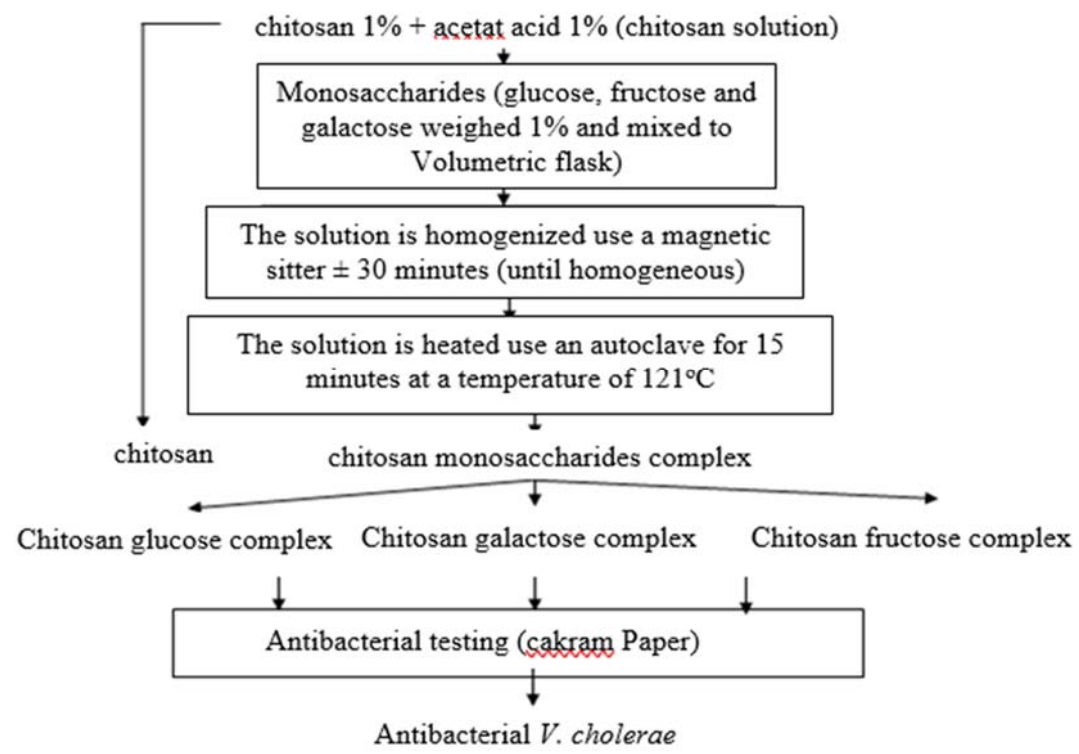

Figure 1 Research framework

homogen). Setelah homogen ditambahkan sebanyak $1 \mathrm{~g}$ (1\%) monosakarida (glukosa, fruktosa dan galaktosa), kemudian volume disesuaikan hingga $100 \mathrm{~mL}$ menggunakan labu ukur. Larutan yang sudah dicampur kemudian disterilisasi dengan autoklaf pada suhu $121^{\circ} \mathrm{C}$ selama 15 menit untuk pembuatan kompleks kitosan monosakarida (CMC) (Mahae et al. 2011).

Analisis antibakteri dilakukan dengan metode kertas cakram yang mengacu metode Kirby-bauer Atlas (1997), dengan V. cholera digunakan sebagai bakteri uji.

Perlakuan yang digunakan dalam penelitian ini adalah ada 4 yaitu :

A0 (1\% Kitosan $+1 \%$ Asam Asetat),

A1 (1\% Kitosan $+1 \%$ Asam Asetat $+1 \%$ Glukosa), A2 ( $1 \%$ Kitosan $+1 \%$ Asam Asetat $+1 \%$ Galaktosa), dan

A3 (1\% Kitosan $+1 \%$ Asam Asetat $+1 \%$ Fruktosa).

\section{HASIL DAN PEMBAHASAN}

Pengujian aktivitas antibakteri dalam menghambat pertumbuhan $V$. cholera dilakukan dengan cara mengukur diameter daerah hambatan (DDH) yang terbentuk disekitar kertas cakram yang telah dicelupkan pada perlakuan kitosan, kompleks kitosan glukosa, kompleks kitosan galaktosa dan kompleks kitosan fruktosa. Metode kertas cakram merupakan metode paling sederhana dan efektif untuk mengetahui aktivitas antibakteri dalam menghambat pertumbuhan $V$. cholera.
Hasil pengukuran diameter daerah hambatan setiap perlakuan dapat dilihat pada Figure 2.

$V$. cholera merupakan bakteri yang terdapat di perairan misalnya sungai, muara sungai, kolam dan laut (Mehrabadi et al., 2012). Bakteri yang sering mencemari makanan laut adalah bakteri marga Vibrio. Bakteri ini merupakan jenis bakteri yang dapat mencemari pangan hasil laut dan menggurangi kualitas ekspor laut. V. cholerae penyebab penyakit kolera. Oleh karena itu, penelitian antibakteri terhadap $V$. cholerae termasuk hal penting untuk menjaga kualitas pangan olahan terutama jenis ikan.

Figure 2 menunjukkan bahwa seluruh perlakuan dapat menghambat pertumbuhan $V$. cholera. Kompleks kitosan monosakarida menunjukkan diameter daerah hambatan sebesar 6,5 sampai 9,0 mm. Perlakuan A0 mempunyai diameter daya hambat (DDH) sebesar 6,5 mm. Perlakuan A1 yaitu kitosan glukosa sebesar $8,6 \mathrm{~mm}$. Perlakuan A2 menggunakan galaktosa dan kitosan sebesar 7,7 mm dan perlakuan A3 memiliki DDH tertinggi 9,0 $\mathrm{mm}$. Perbedaan daya hambat disebabkan penggunaan gula yang berbeda. Hal tersebut disebabkan beberapa bakteri memiliki kemampuan resistensi dengan enzim aminoglicosida N-Asetiltransferase (AATs) (RISBINKES 2011) dan tumbuh baik pada Media yang mengandung gula misalnya Thiosulfate Citrate Bile Salt Sucrose (Yuhantaka 2018) serta penghambatan maksimum pada 


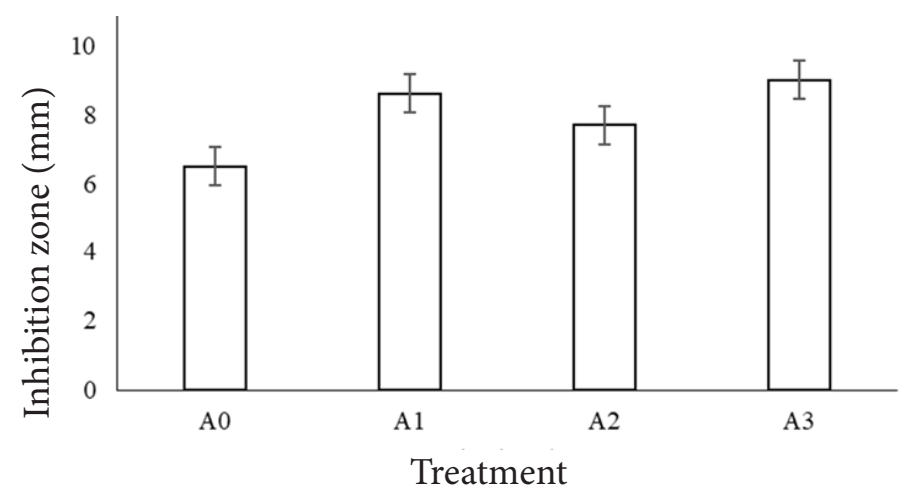

Figure 2 Inhibition zone of $V$. cholerae; A0:1\%(chitosan +acetic acid); A1:1\%(chitosan+acetic acid+ glucose); A2:1\%(chitosan+acetic acid+galactose); A3:1\% chitosan+acetic acid+fructose).

glukosa galaktosa dan glukosa fruktosa sebesar 5 dan 2 (Bag 1974). Hal ini menunjukkan bahwa kompleks kitosan monosakarida memiliki senyawa antibakteri terhadap bakteri gram negatif misalnya $V$. cholerae. Diameter daerah hambatan terbesar terdapat perlakuan A3. Jawetz dan Adelberg (2017) melaporkan bahwa saat isolasi bakteri vibrio, media tambahan yang digunakan adalah fruktosa. Tujuan penambahan fruktosa, Tujuan penambahan fruktosa yaitu menjelaskan fungsi fruktosa dalam menghambat Vibrio.

Bakteri ini merupakan salah satu bakteri yang dapat dihambat oleh kompleks kitosan monosakarida. Sebagian besar isolat-isolat tersebut membentuk zona hambat yang jernih dan zona hambat yang keruh. Zona hambat yang jernih disebabkan produksi antibakteri yang bersifat membunuh bakteri uji sedangkan zona bakteri yang keruh karena antibakteri yang dihasilkan bersifat hanya menghambat perkembangan bakteri. Ada beberapa daerah hambat yang jernih dan zona hambat yang keruh pada pengujian komplek kitosan monosakarida, hal ini diduga karena antibakteri yang dihasilkan bersifat bakteriostatik. Kompleks kitosan fruktosa memperlihatkan diameter daerah hambatan yang jernih pada $V$. cholerae.

Masing-masing dari bakteri memiliki struktur yang berbeda misalnya bakteri gram positif terdiri dari dinding sel yang tebal dan berlapis tunggal dengan komposisi dinding sel terdiri dari lapisan peptidoglikan dan asam teikoat sedangkan bakteri gram negatif misalnya $V$. cholerae mempunyai kandungan peptidoglikan yang dapat menentukan bentuk sel serta memberikan kekakuan yang dibutuhkan untuk melindungi dari bakteri perombakan osmotik, kitosan memiliki kemampuan menghambat sintesis petidoglikan sehingga bakteri tidak dapat melakukan replikasi karena dinding peptidoglikan koloni bakteri tersebut dihambat senyawa dari kitosan dan kompleks kitosan monosakarida. Hal tersebut membuat bakteri gram negatif tidak mampu mereplikasi diri dan tumbuh dalam suatu medium. Selain itu, sifat penting kitosan sebagai antibakteri disebabkan muatan positif dalam larutan asam, karena gugus amina pada molekul kitosan mengikat proton yang sesuai (Pebriani et al. 2012). Selain itu kitosan berpotensi sebagai bahan antimikroba karena mengandung enzim lisosim dan gugus aminopolisakarida (Rilda et al. 2014).

Bakteri gram negatif yaitu $V$. cholerae mempunyai ketahanan antimikroba yang lebih baik. Bakteri gram negatif memiliki sistem seleksi terhadap benda-benda asing yaitu pada lapisan lipoposakarida dan struktur sel-sel mikroba lebih komplek, sedangkan bakteri gram positif lebih sederhana sehingga senyawa antimikroba mudah untuk masuk ke dalam sel dan menemukan sasaran untuk bekerja (Zuhud 2011). Pada penelitian ini beberapa perlakuan efektif, yaitu A3, dalam menghambat bakteri negatif misalnya $V$. cholerae. Hal ini disebabkan sifat kitosan itu sendiri dan terbentuknya reaksi Maillard dari pencampuran monosakarida. 

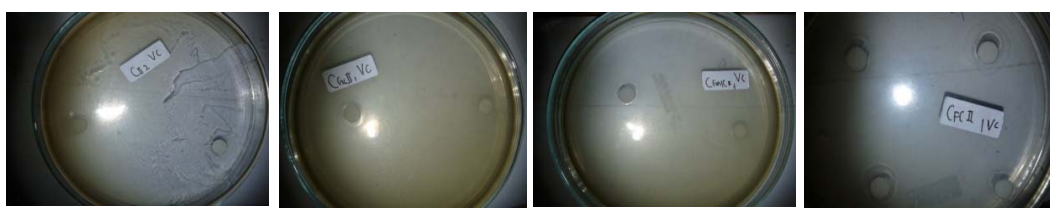

Figure 3 Inhibition zone of chitosan monosaccharides complex in V. cholerae

\section{KESIMPULAN}

Komplek kitosan monosakarida memiliki aktivitas antibakteri dalam menghambat $V$. cholerae. Diameter daya hambat bakteri tertinggi $V$. cholerae $(9 \mathrm{~mm})$ dengan penggunaan gula fruktosa.

\section{UCAPAN TERIMA KASIH}

Terima kasih kepada Ketua YP4SS, Ketua Pembina Universitas Sumatera Selatan dan laboratorium Teknologi Hasil Pertanian Universitas Sriwijaya atas dukungan yang telah diberikan sehingga penelitian dapat terlaksana.

\section{DAFTAR PUSTAKA}

Ali H, Baehaki A, Lestari S. 2017. Karakteristik edible film gelatin-kitosan dengan tambahan ekstrak genjer (Limnocharis flava) dan aplikasi pada pempek. Jurnal Teknologi Hasil Perikanan-Fishtech. 6(1) :26-38.

Atlas R.M. 1997. Principles of Microbiology. Second Edition. Iowa: WNC Brown.

Bakry AM, Chang M, Xiong S, Yin T, Zhang B, Huang Q. 2018. Chitosan-glucose Maillard reaction products and their preservative effects on fresh grass carp (Ctenopharyngodon idellus) fillets during cold storage. Journal of the Science of Food and Agriculture. 99(5): 2158-2164.

Bag J. 1974. Glucose inhibition of the transport and phosphoenolpyruvate-dependent of galactode and fructose in Vibrio cholerae. Journal of Bacteriology. 118 (2): 764-767.

Jawetz. M, Adelberg. 2017. Mikrobiologi kedokteran. Jakarta (ID): EGC.

Lestari S, Baehaki A, Meliza R. 2019. Aktivitas antibakteri kompleks kitosan -monosakarida terhadap patogen dalam surimi ikan gabus sebagai model matriks pangan. Jurnal Pengolahan Hasil Perikanan Indonesia. 22(1): 80-88.

Liang C, Lingm Y, Wei F, Huang L, Xiaomao L.
2020. A novel antibacterial mesh coated by chitosan and tigecycline for pelvic floor repair and its biological performance. Regenerative Biomaterials. 7(5): 483-490.

Lin Y, Lin Y, Lin M, Lin H. 2019. A novel chitosan alleviates pulp breakdown of harvested longan fruit by suppressing disassembely of cell wall polysaccharides. Carbohydrate Polymers. 217 (1): 126-134.

Mahae N, Chalata C, Muhamud. 2011. Antioxidant and antimicrobial properties of chitosan sugar complex. Journal International Food Research. 18(4) : 15431551.

Pebriani RH, Rilda Y, Zulhadjri. 2012. Modifikasi komposisi kitosan pada proses sintesis komposit $\mathrm{TiO}_{2}$-kitosan. Jurnal Kimia Unand. 1(1): 40-47.

Baptista RC, Horita CN, Sant'Ana AS. 2020. Natural products with preservative properties for enhancing the microbiological safety and extending the shelf-life of seafood: A review. Food Research International. 127: 1-86.

Rilda Y, Asnilawati R, Alif A. 2014. Sintesis nanoclustertio2-sio2/kitosan dengan penambahan surfaktan sds. Jurnal Kimia Unand. 3(3): 12-16.

[RISBINKES] Riset Pembinaan Kesehatan. 2011. Laporan Penelitian Pola Resistensi Bakteri Vibrio cholerae dari Isolat KLB Diare Kabupaten Jember dan Bogor Tahun 2010. Pusat Biomedis dan Teknologi Dasar Kesehatan. Jakarta (ID) :Badan Penelitian dan Pengembangan Kesehatan Kementerian Kesehatan RI.

Sari SR, Baehaki A, Lestari SD. 2013. Aktivitas antioksidan kompleks kitosan monosakarida (chitosan monossacharides complex). Jurnal Teknologi Hasil Perikanan Fishtech. 2 (1): 69-73.

Sari SR, Baehaki A, Lestari SD. 2019. Pemanfaatan kitosan dengan variasi gula sebagai potensi pengawet alami makanan 
(Pengujian bakteri Pseudomonas aeruginosa dan Bacillus subtilis). Prosiding Seminar Nasional II Hasil Litbangyasa Industri.

Toynbe S, Baehaki A, Lestari SD. 2015. Pengaruh aplikasi kitosan sebagai coating terhadap mutu dan umur simpan daging giling ikan gabus (Channa striata). Jurnal Teknologi Hasil Perikanan Fishtech. 4(1): 67-74.
Yuhantaka N. 2018. Identifikasi bakteri Vibrio cholerae pada terasi tanpa penambahan dan dengan penambahan ekstrak kulit buah naga merah (Hylocereus polyrhizus) sebagai pewarna alami. (Karya Tulis Ilmiah) Jombang(ID) : Sekolah Tinggi Ilmu Kesehatan Insan Cendekia Medika.

Zuhud EAM. 2011. Aktivitas ekstrak kedawung (Parkia roxburghii G. Don) terhadap bakteri patogen. Jurnal Teknologi dan Industri Pangan. 12(1): 6-12 . 